УДК 786. 2+78. 071

\author{
Лю Кетін, \\ кандидат мистецтвознавства, \\ викладач музичної школи в Гуанчжоу (Китай) \\ kate576471513@qq.com \\ ORCID:0000-0003-1326-1210
}

\title{
СТИЛЬОВІ ПРИНЦИПИ КИТАЙСЬКОГО МИСТЕЦТВА ХХ СТОЛІТТЯ Й МУЗИКА ТАЙВАНЮ
}

Метою даного дослідження $є$ виокремлення історично зумовленого оригінального регіонального внеску Тайваня у сукупний мистецький здобуток великого Китаю. Методологічною основою роботи $\epsilon$ інтонаційний підхід, що фіксує єдність музичного й мовного факторів, який є органічним для традицій музики Китаю (див. роботи Ма Вэй та ін. Компаративний метод у методологічному комплексі інтонаційності здобуває самозначимий зміст - у дусі відповідних робіт Б. Асафьева і його послідовників в Україні. Особливий методологічний зміст мають також праці Лю Бинцяна, що піднімають проблему духовно-семантичної обумовленості кардинальних стильових поворотів у світовому мистецтві й у культурі в цілому. Наукова новизна роботи базується на виявленні спеціального стилістичного нахилу в музичній регіоналістиці Тайваню, що не збігається із загальними стильовими установленнями материкового китайського ареалу. Висновки. Китайська музика на протязі ХХ ст. активно вбирала європейські впливи, а із встановленням КНР у 1949 р.в тих музичних європеїзмах головуючою постає традиціоналістська стильова лінія, що заохочувалася співдружністю з СРСР. Остання в межах Китаю була принципово «новою музикою», що протистояла національній традиції, драматично-театральній, орієнтованій на масштабність цзінцзюй. На відміну від тих материкових ознак китайського мистецтва, острівний Тайвань тяжів до західного модерну у проєвропейських втіленнях і концентрувався на камерності фортепіанного репертуару.

Ключові слова: стиль в музиці, музичний жанр, китайське мистецтво, регіоналізм в мистецтві, творчі традиції Тайваню.

Лю Кетин, кандидат искусствоведения, преподаватель музыкальной школы в Гуанчжоу (КНР)

Стилевые принципы китайского искусства XX века и музыка Тайваня

Целью данного исследования является выделение исторически обусловленного оригинального регионального взноса Тайваня в совокупные художественные достижения великого Китая. Методологической основой работы является интонационный подход, фиксирующий единство музыкального и речевого факторов, что органично для традиций музыки Китая (см. работы Ма Вэй и др.) Компаративный метод в методологическом комплексе интонационности приобретает самозначимый характер - в духе соответствующих работ Б. Асафьева и его последователей в Украине. Особый методологический смысл имеют также труды Лю Бинцяна, поднимающие проблему духовно-семантической обусловленности кардинальных стилевых поворотов в мировом искусстве и в культуре в целом. Научная новизна работы базируется на выявлении специального стилистического уклона в музыкальной регионалистике Тайваня, который не совпадает с общими стилевыми установлениями материкового китайского ареала. Выводы. Китайская музыка на протяжении XX века активно вбирала европейские влияния, а с установлением КНР в 1949 году .в этих музыкальных европеизмах преобладающей становится традиционалистская стилевая линия, которая поддерживалась содружеством с СССР. Последняя в пределах Китая была принципиально «новой музыкой», которая противостояла национальной традиции, драматически-театральной, ориентированной на масштабность цзинцзюй. В отличие от этих материковых признаков китайского искусства, островной Тайвань тяготел к западному модерну в проевропейских воплощениях и концентрировался на камерности фортепианного репертуара.

Ключевые слова: стиль в музыке, музыкальный жанр, китайское искусство, регионализм в искусстве, творческие традиции Тайваня.

Liu Ke Ting, PhD of Arts, teacher music school in Guangzhou (China)

Stile principles of chinese art of the XX century and music of Tai Wang

The purpose of the article is a separation historically conditioned original regional donation Tai Wang in total artistic achievements of great China. The methodology of the work is the intonation approach, fixing unity music and speech factor that is common for the tradition of the music of China (refer to work Ma Way and others. The comparative method in methodological complex intonation theories gains the independent character - in spirit corresponding to the work of B. Asafiev and his followers in Ukraine. The special methodological sense has also works by Liu Bing Cjiang, raising the problem of spiritual-semantic determinism of cardinal style tumbling in world art and

СЛю Кетін, 2019 
culture as a whole. The scientific novelty of the work is based on revealing the particular stylistic gradient in music regionalism of Tai Wang, which does not comply with the general style determinations of continental China. Conclusions. The Chinese music on length XX century actively absorbed European influences. Still, with resolution CNR in the 1949 year, these music European indications dominating becomes a tradition style line, which was supported by commonwealth with USSR. The last within China was in principal "new music," which withstood the national tradition, dramatic-theatrical, oriented on the big size of Pe King opera. Unlike these continental signs of Chinese art, insular Tai Wang gravitated to western modernist style in proeuropian entailments and concentrated on chamber piano repertoire.

Key words: style in music, music genre, chinese art, regionalism in art, creative traditions Tai Wang.

Актуальність теми дослідження зумовлена обставинами буття сучасного мистецтва - i так склалося від XX ст., - в якому очевидними стали процеси локалізації, регіоналізації, нарешті, провінціалізації культури й мистецтва, що представляють націю і відповідний мистецький осередок. Дані процеси склалися на противагу інтегрально-глобалістським тенденціям, в чомусь гармонізуючи, а в чомусь жорстко опонуючи протилежностям планетарно узагальнюючих процесів та акцій.

Китайське мистецтво має давню історію, в якій взаємодії тих чи інших частин великої держави давали «забарвлення» сукупному національному культурному буттю. Множинність етносів і націй, що складають підсумковий національний принцип, який зв'язаний, перш за все, з культурним надбанням етносу хань, на певних етапах історичного розвитку круто мінявся 3 опорою на деяке провінційне надбання. У XX ст. соціальна універсалізація мистецтва Китаю, що підштовхнула інтеграційні спрямування мистецтва, у тому числі у єднанні з європейськими художньо-культурними надбаннями, зіштовхнулася 3 регіоналізацією Тайваню. Останній волею історичних обставин відійшов від Китаю, а згодом від 1960-х знов був включений у загальнонаціональний обсяг, але 3 відповідними виробленими регіональними показниками.

Даний мистецький процес регіоналізації тайваньської музичної культури довго не помічався, в описах історії музики Китаю спеціально не обговорювався. В нарисах академічних довідкових видань (див. [2, с.572-573; 3, с. 813-815], характеризуючи сукупні ознаки китайської музики, регіональний аспект тайваньського внеску не торкався. Навіть в книзі Лю Бінцяна [4], де спеціальне місце представлене «провінційній» літературі оточення Лу Сіня та ін., тайваньський музичний феномен не порушувався.

Метою даного дослідження $€$ виокремлення історично зумовленого оригінального регіонального внеску Тайваня у сукупний мистецький здобуток великого Китаю. Методологічною основою роботи є інтонаційний підхід, що фіксує єдність музичного й мовного факторів, який є органічним для традицій музики Китаю (див. роботи Ма Вэй та ін. Компаративний метод у методологічному комплексі інтонаційності здобуває самозначимий зміст - у дусі відповідних робіт Б. Асафьева і його послідовників в Україні. Особливий методологічний зміст мають також праці Лю Бінцяна, що піднімають проблему духовно-семантичної обумовленості кардинальних стильових поворотів у світовому мистецтві й у культурі в цілому. Наукова новизна роботи базується на виявленні спеціального стилістичного нахилу в музичній регіоналістиці Тайваню, що не збігається із загальними стильовими установленнями материкового китайського ареалу.

Мистецтво Китаю, волею історичних обставин, у ХХ сторіччі виявилося утягненим в активну взаємодію з європейським світом, у тому числі це участь на стороні Росії в Російсько-японській війні й згодом антияпонська ж позиція в подіях середини XX століття. Але при цьому Тайвань виявився під японською окупацією, що визначило деякі важливі переваги художньої сфери останнього. Участь у європейських політичних перипетіях визначили соціальні потрясіння Китаю, з яких самим істотним виявився соціальний вибух 1911 року, що висунув значиму в міжнародному соціалістичному русі фігуру Сун Ятсена. Ідеї інтернаціоналізму, що проникнули в китайський соціум, визначили чітку установку на впровадження музичної освіти європейського типу, що й було здійснено від 1920-х років. Одночасно китайський феномен активно обговорювався в європейському ареалі, породжуючи нові запозичення, паралелі й взаємодії.

У дослідженні Лю Бінцяна відзначені «хвилі» китайського впливу на європейський культурний світ і співвіднесені з ними хронологічно й фактологічно етапи завоювань китайського мистецтва XX століття [4, 255-285]. Дивні зустрічні спрямованості цих зовсім автономно зароджуваних рухів. Так, захват символістів Свропи, в особі П.Клоделя, М.Волошина, К. Дебюссі, Г.Малера й ін. у зв'язку з упізнанням у китайському феномені забутих цінностей готичноїренесансної Європи мав певну - недетерміновану - реакцію в проверистській «літературі рідних місць», у центрі якої виявився по-китайски переломлений феномен А.Чехова (Лу Сінь - «китайський Чехов»). 
Модерністський вихід Б. Брехта 3 його комуністично-агітаційною програмою - мав як би продовження в будівництві Сяо Юмеєм європеїстського принципу музичної освіти в Китаї. А от 3 1950-х політично й музично Китай наполегливо виявляється у впливі на Європу, що завершилося торжеством прокитайски вибудуваної творчості корейця Ісанга Юна й китайця Тан Дуна в композиторській творчості. Так вперше виявилася участь у європейській системі - неєвропейських авторів, до речі,тих що надзвичайно активно виявили свою національну приналежність у творчості.

Сказане дозволяє пояснити сприятливий художній контекст, що формував контакт мистецтва Тайваню 3 материковим Китаєм при всіх шорсткостях політико-ідеологічних розбіжностей, що установлювалися протягом другої половини XX сторіччя.

Китайське музичне мистецтво середини XX століття визначилося підйомом, що визначило його зльот у кінці минулого сторіччя: від оригінальних пошуків «Сивої дівчини» Ма Ке й спектаклів Культурної революції до композиторського «шаріння» Тан Дуна, що стало кульмінаційною точкою художнього сходження Китаю в XX столітті. У роботі Лю Бінцяна дана наступна характеристика цього епохального моменту в житті китайського музичного мистецтва:

«З'єднання театрального досвіду Китаю і Європи здійснено тут, як це видно із сьогоднішнього дня, дуже сміло, майже на грані театру абсурду. Помітимо, саме в 1950 -е у Франції румун Іонеско й ірландець Беккет вибудували тип спектаклю, що одержав назву 'театру абсурду'. Але в ті ж 1950-і роки Л. Бернстайн створює 'драматичний мюзикл'. Його 'Вестсайдська історія' (1957) обійшла театральні підмостки с віту, становлячи деяке 'знамення часу'. I хоча ні в Китаї, ні в Радянському Союзі в 1950-ті ця вистава не ставилася (про неї довідалися в цих країнах набагато пізніше), риси, подібні з 'драматичним мюзиклом', знаходимо в ряді видатних кінокомпозицій - 'Карнавальна ніч' (1956), 'Висота' (1957). Але також... є зазначені епохальні риси - в 'Сивій дівчині' китайських авторів» [4, 174-175]. Далі названий автор уточнює:

«Як сказано вище, з погляду і європейської, і китайської традиції в опері 'Сива дівчина' є риси абсурдизму. Сучасний сюжет, симфонічний європейський оркестр із впровадженими в нього соло, що нагадують народний китайський інструментарій - i одночасно має місце багатокартинна драматургія традиційних китайських вистав, спів у манері національної опери. Революційні події в китайській провінції - і одночасно головна героїня, іiї оточення показані ...у балетній європейській стилістиці 'танцю на пуантах'(!). Таке з'єднання 'високого' і 'низького' у стилі, національного й позанаціонального в композиції й прийомах, дійсно, об'єктивно свідчать про абсурдистськоекспериментальний характер вистави... Але саме дивне - це те, що твір був з ентузіазмом прийнятий сучасниками, а в наш час становить частину 'золотого фонду' національної художньої традиції» [4, 175].

Наведені характеристики свідчать про надзвичайно плідну атмосферу буття Китаю в 1950-е роки, коли Тайвань був уведений до складу КНР. Одночасно із зазначеними проявами оригінальних ліній національного театру в Китаї бурхливо установлюється європейська система музики, у тому числі це інтенсивний розвиток фортепіанної школи, підготовлене титанічними зусиллями по впровадженню в китайську систему музичної освіти за досвідом європейських консерваторій. У роботі В.Батанова виділене ім'я Сяо Юмея як одного із самих послідовних і талановитих музикантів, який ретельно й глибоко здійснював впровадження європейської системи «музики для слухання» у мистецтво Китаю. Названий автор констатував:

«Сяо Юмей гаряче любив європейську музику, пропагував творчість класиків європейського мистецтва, створював навчальні посібники й відкривав установи за європейською системою» $[1,133]$.

В іншій книзі - у праці Лю Бінцяна - представлена ємна характеристика здійснень етапу Культурної революції 1960-х років, коли в числі «8 кращих вистав» виявилися опера цзінцзюй і балет «Жіночий батальйон Червоної Армії»:

«Актуальність його показу в сучасності, при тім що дія відноситься до подій антияпонської війни 1940-х років, обумовлено увагою до фемінізації державно-управлінської системи країни, історія яких містить чудові зразки жіночої адміністративної ініціативи, бойового мистецтва, що, до речі, фіксує цзінцзюй, одним із провідних типажів якої $є$ дань-войовниия, виразність ролі якої визначається акробатично-танщювальною підготовленістю актора (акторки) при поданні даного персонажу. Зазначений спектакль гіперболізує вказаний типологічний показник традиційної вистави, створюючи в результаті оригінальне переломлення ідеї. Не дивно, що Дж. Адамс у своїй 'китайській' опері 'Ніксон у Китаї' розмістив саме дану композицію - і ідеологічно, і естетично вона відповідає тому, що варто було б назвати 'музичною емблемою комуністичного Китаю'» [4, с. 309-310]. 
Цитований автор докладно пояснює органіку звершеного у національному театрі Китая, у якому визначена була установка на актуалізацію традиції в контексті завдань мистецтва XX століття в цілому:

«Балетний варіант спектаклю утворив автономізований принцип виконання балетних складових цзінцзюй, пекінської опери, які в цьому типі національного театру надзвичайно значимі й навіть в окремих випадках (див. 'Потрійна розвилка', 'Дебош у Небесному палаці'... заміняють спів як такий» $[4,310]$.

Вище вже відзначалося, що пекінська опера має два напрямки: 'цивільні' і 'військові' п'єси. 3 них перші, в основному, грунтувалися на співі, демонструючи в буттєвих сюжетах надповсякденний зміст повсякденного. Другі ж тяжіли до історичної тематики, насичені танцювальними й акробатичними номерами, демонструють прийоми ушу. Але спільним моментом для обох типів п'єс $€$ гимнічно-ошатний настрій, надповсякденна значимість того що відбувається, навіть якщо це сучасний сюжет і позбавлений глибоких конфліктних подійових ситуацій. Звідси - резюме Лю Бінцяна: «Як бачимо, спектакль 'Жіночий батальйон Червоної армії' демонструє тип 'військової' п'єсивідчого хореографічний варіант іiї виявився в центрі уваги постановників» [там само, 310].

Наведені факти сходження китайського театрального мистецтва мали своєю паралеллю успіхи китайських піаністів у світовому розкладі, що забезпечило їм одне 3 лідерствуючих положень у планетарних масштабах до початку XXI сторіччя. Зіркою світового значення визначився Лю Шикунь, лауреат Конкурсу Чайковського в Москві, що постраждав у період Культурної революції, - але дивний прорив саме в піаністичній сфері був здійснений. I спадкоємцями цієї фортепіанної слави Китаю кінця 1950-х - початку 1960-х років стала ціла плеяда блискучих піаністів, які затвердилися в міжнародній яких.

Політичні й економічні пертурбації, які потрясали Китай у десятиліття, що пішли після Революції 1960-х років, не закреслювали того високого змісту, що відзначив музичні й художні досягнення в цілому великої країни, у яку згодом влилися сили, сформовані регіонально, а саме, музичні нагромадження Тайваню як частини Китаю, на певному історичному відрізку автономізованого у своєму розвитку й того що не приймав ті або інші посилання материкової складової китайського образу думки.

Між 1950-ми і 1960-ми роками Тайвань відзначений був значним економічним ростом, завдяки економічній програмі допомоги Сполучених Штатів. Темпи зростання промислового виробництва досягали 10 \% у рік, і поступово наростання багатства привів до рішучих соціальних змін. Протягом наступних двох десятиліть виникли два літературних рухи, які мали вплив на суспільну думку, на політичні й соціальні аспекти, i, вже тим більш, безпосередньо на сферу мистецтва. Точно так само як автори материкової музики, що мала хождіння на Тайвані, користувалися сильною підтримкою Націоналістичного уряду, на літературній сцені домінували антикомуністичні й антияпонські опуси й літературні нариси авторів, що писали на справжньому мандаринському наріччі китайської мови. Незважаючи на безсумнівну літературну цінність цих робіт, нове молоде покоління модерністів кинуло виклик представлюваному ними реалізму, вважаючи цей рух ідеологічним контролем над письменниками.

Нове покоління тайваньской інтелігенції прийняло західну філософію й відхилило нав'язуваны соціальні установки, засновані на конфуціанських традиціях, установлених тисячу років тому. Піддавшись впливу фрейдистського психоаналізу й західного екзистенціалізму, тайваньські письменники-модерністи робили сильний акцент на раціоналізмі, людському поводженні й боротьбі із забобонами. Тенденція, відома як "Сучасний літературний рух 60-их", стала настільки приголомшливою, що швидко поширилася майже на всі області мистецтва - живопис, театр і музику. У цей час, в 1960 році, композитор Ченг Ху Кеу дав перший сольний концерт, що складався тільки 3 йогоі творів, що і ознаменувало нову еру в розвитку тайваньської музики.

Коли в 1959 році Ченг Хукеу повернувся на Тайвань із Парижа, де він одержав свою освіту, більшість тайваньских композиторів усе ще застосовували традиційні, тональні композиційні методики, які дісталися їм у спадщину від китайських професорів 3 материка. Таким чином, стиль Ченга Хукеу, що широко використовував композиційні методики XX сторіччя, розглядався як сміливий і новаторський експеримент.

Ченг Хукеу згадував:

"...поява моїх перших музичних робіт у тих концертних програмах не викликало особливого занепокоєння в композиторів, адже навіть я не міг писати по-справжньому сучасну музику. Однак, подібна техніка композиторського письма була абсолютно новою мовою для сучасної музики на 
Тайвані... Незважаючи на те, що сучасні методи композиції вже існували більш, ніж половину сторіччя... на Тайвані, це все було ще невідомо..." [5, 70].

Після концерту з авторських творів у газетах і журналах буквально протягом половини місяця з'явилися більше десяти критичних відгуків. Ці інтенсивні обговорення в музичній пресі зачіпали самолюбство й вплинули на розум майбутніх композиторів. Навіть при тім, що більшість оглядів негативно відзивалися щодо сольного концерту Кеу, частина захоплених відкликів, звичайно, привернули увагу багатьох композиторів до сучасної музики.

Ченг Хукеу запросив трьох інших композиторів і організовував музичний колектив, назва якого дослівно перекладається як "Майстерня для виготовлення музики". Ця група видавала місцеві музичні праці й представила за період між 1961-72 pp. у цілому вісім нових музичних концертів. Слідом за колективом Ченга Хукеу, з'явилися інші групи композиторів, такі, як "Нова музична прем'єра", " Жанг-Ланг" (річкова хвиля), "Ву Рэн" (п'ять чоловіків) і група "Соняшник".

Композиторські прийоми, які застосовувалися авторами протягом того періоду, були сформовані під впливом музики Дебюссі, Бартока та інших композиторів початку XX сторіччя. Справедливо нагадати, що західний напрямок у розвитку тайваньської музики запізнився, щонайменше, на половину сторіччя. Більш ранній стиль змішання класичної тональної системи 3 пентатонними мелодіями використовувався рідко, а те й повністю був ігнорований композиторами нової хвилі.

Замість цього композитори шукали нові підходи в рамках різних західних композиційних методик XX століття, намагаючись знайти точки сполучення з китайською ладовою системою. Деякі композитори надали перевагу тому, щоб узяти за основу китайську ладогармонічну систему й національний музичний матеріал як теоретичну основу своїх робіт, а музичні прийоми Заходу додавали потроху, як данину моді.

Цікаво відзначити, що в цей період тотальної модернізації й "вестернізації" музичної сцени, на відміну від інших областей мистецтва, майже не торкалися ідеологічного аспекту, і композитори були більш залучені в технічну сторону творчого процесу. Щоб виражати особисті почуття й зберегти культурну ідентичність, композитори продовжували використовувати китайську музику, літературу й картини для свого натхнення.

У більше пізні роки Ченг Хукеу назвав пануючі композиційні стилі цього періоду "китайською модернізацією музики", які фактично означали освоєння стилів i методик, представлених у європейській творчості. Однак тенденція модернізації в 1960-ті роки стала важливим поворотним моментом у розвитку західної музики на Тайвані. Саме в 60-ті роки успіхи, досягнуті рухом модерністів, яких підтримали більшість людей мистецтва й інтелігенції, а так само посилення в суспільстві капіталістичних настроїв, підігрітихя швидким економічним ростом, неминуче привели до зниження впливу традиційного тайваньського мистецтва.

Наприкінці 1960-их деякі автори, вчені й художники почали опиратися перевазі прозахідному модернізму й хотіли привнести в мистецтво власне середовище й культуру. Суперечки між цими двома угрупованнями привели до початку так званої "Сучасної поетичної дискусії" (1972 рік), і ці суперечки не вщухали до кінця десятиліття. Фактично, це явище відбило зростаюче розуміння культурної ідентичності в середовищі артистів і інтелігенції протягом 70-их, і пізніше було названо тенденцією "Повернення до рідних коренів".

Між 1966 і 1967 pp. Ченг Хукеу і Вей Ляньши ініціалізували безпрецедентний проект "Збір тайванських народних пісень", що був найбільш масштабним заходом щодо збору народних пісень із коли-небуть початих на Тайвані. Їх колекції включали народні пісні й від автохтонних племен, і від китайців провінції Ханипуй. Згідно Ши, цей проект мав три важливих моменти:

1) зберігати, досліджувати й зрозуміти народні пісні й звичаї китайців провінції Ханьшуй та інших;

2) відгородити тайваньську музичну культуру від швидкоплинних змін суспільства, пов'язаних 3 індустріалізацією й модернізацією;

3) осягти душу свого народу й створювати рідну йому музику.

Цей проект мав прямий вплив на естетичні погляди композиторів на тематику створюваних музичних творів, і зібрана колекція залишається дотепер одним з найважливіших ресурсів, на які опираються місцеві композитори. Особливо відзначаємо збіг зазначених заходів охорони національно-регіональних якостей рідного мистецтва 3 тенденціями «провінціалізму» у художньому світі, що найбільше демонстративно відбито в коріннях рок-н-ролу, визначених творчістю майстрів американського Півдня-Заходу, що третирувався в США послу поразки південців у війні 1863 1865 гг. 
Висновки. Китайська музика на протязі XX ст. активно вбирала європейські впливи, а із встановленням КНР у 1949 р.в тих музичних європеїзмах головуючою постає традиціоналістська стильова лінія, що заохочувалася співдружністю з СРСР. Остання в межах Китаю була принципово «новою музикою», що протистояла національній традиції, драматично-театральній, орієнтованій на масштабність цзінцзюй. На відміну від тих материкових китайських ознак, острівний Тайвань тяжів до західного модерну у проєвропейських втіленнях і концентрувався на камерності фортепіанного репертуару.

1. Батанов В.Ю. Универсализм композиторской личности в музыкальном искусстве XX - начала XXI в. Канд.дисс. 17.00.03. Одесская нац.муз.академия имени А.В.Неждановой. Одесса, 2016. 186 с.

2. Китайская литература Краткая литературная энциклопедия в 9-ти томах. Т. 3. Москва, 1966. С. 547573.

3. Китайская музыка [Е.Виноградова, А.Желоховцев Музыкальная энщиклопедия в 6-ти томах. T. 2. Гондольера -Корсов. Москва, Издат.Советская энциклопедия, 1974. С.807-815.

4. Лю Бинцян Музыкально-исторические параллели развития искусства Китая и Европы. Монография по истории культуры для музыкальных академий, университетов и вузов искусства. Одесса: Астропринт, 2014. 440c.

5. Ван Вэй Жен. Китайцы и современники: Шу Лонг Ма. Музыка и звукозапись. № 153. Тайбэй: Жи Ли, 1984. C. $80-86$.

\section{References}

1. Batanov V. (2016). Universalism of composer personalities in music art XX - begin XXI ct. Candidate's thesis, 17.00.03.Odessa state music academy of the name A.V.Nezhdanova. Odesa. [in Ukrainian]

2. Chinese literature (1966). Short literary encyclopedia in 9 volumes. V. 3. Moscow. pp. 547-573 [in Russian].

3. Chinese music [E.Vinogradova, A.Zhelohovcev. Musical encyclopedia in 6 volumes. Editor-in-chief Ju.Keldysh. V. 2. Moscow, Sov.encyklopedija. pp. 807-815. [in Russian]

4. Liu Bin Chang (2014). Music-history parallels of the development of the art to China and Europe. Monograph on histories of the culture for a music academy, university and high school art. Odessa: Astroprint. [in Ukrainian]

5. Van Vej Zhen (1984). Chinamans and contemporaries: Shu Long Ma Music and phono-inscription. № 153. Tay Bey, Zhy Li. pp. 80-86. [in Chinese]. 